\title{
ANALISIS PENGEMBANGAN KAWASAN WISATA ALAM AIR TERJUN TAHAPAN TELU BERDASARKAN POTENSI BIOFISIK
}

\section{ANALYSIS OF TAHAPAN TELU WATERFALL NATURAL TOURISM AREA DEVELOPMENT BASED ON BIOPHYSICAL POTENTIAL}

\author{
Fernando Perdana Londong ${ }^{(1)}$, Fabiola B. Saroinsong ${ }^{(2)}$, Maria Y. M. A. Sumakud ${ }^{(2)}$
}

1) Mahasiswa Program Studi Ilmu Kehutanan, Fakultas Pertanian, Universitas Sam Ratulangi, Manado

2) Dosen Program Studi Ilmu Kehutanan, Fakultas Pertanian, Universitas Sam Ratulangi, Manado

*Penulis untuk korespondensi: fernandoperdanalondong@gmail.com

Naskah diterima melalui Website Jurnal Ilmiah agrisosioekonomi@ unsrat.ac.id Disetujui diterbitkan
Rabu, 7 April 2021

Jumat, 28 Mei 2021

\begin{abstract}
This study aims to analyze the biophysical potential of the Kali Tahapan Telu Waterfall area. The research was conducted in August 2020 at Kali Tahapan Telu Waterfall, Kali Village, Pineleng SubDistrict, North Sulawesi. This study uses a survey method for primary data collection, namely by conducting interviews with parties related to the management of this natural tourism area, as well as direct observation in the tourist area of Kali Tahapan Telu Waterfall and the surrounding environment. Secondary data were obtained from existing references and agencies. Data analysis used in this study was the scoring technique. The results of this study indicate that the results of the biophysical potential of Kali Tahapan Telu Waterfall are in the medium category. The development of tourist areas can be done by utilizing various biophysical potentials as well as overcoming the obstacles encountered. Addition and development of tourist activity options, addition and enrichment of good views through attractive landscape designs, management of biodiversity including endemic types, utilization of distinctive architecture in supporting buildings, utilization of local arts and culture in increasing tourist attraction, infrastructure enhancement in the form of viewing posts or gazebos, as well as providing souvenirs based on local resources.
\end{abstract}

Keywords: biophysics; tourism potential development; nature tourism

\section{ABSTRAK}

Penelitian ini bertujuan untuk menganalisis potensi biofisik kawasan Wisata Alam Air Terjun Kali Tahapan Telu.Penelitian dilaksanakan di Bulan Agustus 2020 di Air Terjun Kali Tahapan Telu, Desa Kali, Kecamatan Pineleng, Sulawesi Utara. Penelitian ini menggunakan metode survei untuk pengumpulan data primer yaitu dengan melakukan wawancara dengan pihak-pihak terkait pengelolaan kawasan wisata alam ini, serta observasi langsung di kawasan wisata Air Terjun Kali Tahapan Telu dan lingkungan sekitarnya. Data sekunder diperoleh dari referensi yang ada serta instansi. Analisis data yang digunakan dalam penelitian ini adalah dengan teknik skoring. Hasil penelitian ini menunjukkan bahwa hasil potensi biofisik Air Terjun Kali Tahapan Telu termasuk kategori sedang. Pengembangan kawasan wisata dapat dilakukan dengan memanfaatkan berbagai potensi biofisik sekaligus mengatasi kendala yang ditemui. Penambahan dan pengembangan pilihan aktivitas wisata, penambahan dan pengkayaan good view melalui desain lanskap yang menarik, pengelolaan keanekaragaman hayati termasuk jenis endemik, pemanfaatan arsitektur khas dalam bangunan penunjang, pemanfaatan seni dan budaya daerah dalam meningkatkan daya tarik wisata, penambah infrastruktur berupa gardu pandang atau gazebo, serta penyediaan cenderamata berbasis sumber daya lokal.

Kata kunci: biofisik; pengembangan potensi wisata; wisata alam 


\section{PENDAHULUAN}

\section{Latar Belakang}

Pembangunan pariwisata memiliki peran signifikan dalam aspek ekonomi, sosial dan lingkungan sebagai berikut. Sektor pariwisata mengkontribusi devisa dari kunjungan wisatawan mancanegara dan produk domestik bruto (PDB) beserta komponenkomponennya. Pariwisata berperan dalam penyerapan tenaga kerja, apresiasi seni, tradisi dan budaya bangsa dan peningkatan jati diri bangsa. Selain itu, pariwisata berperan sebagai pelestarian fungsi lingkungan disekitar kawasan wisata (Jibran dkk, 2016).

Menurut Ridwan (2012), objek wisata merupakan sesuatu yang memiliki keunikan, keindahan dan nilai yang berupa keanekaragaman kekayaan alam, budaya dan hasil buatan manusia yang menjadi sasaran atau tujuan kunjungan wisatawan. Keanekaragaman sumber daya alam seperti keindahan alam, keunikan, keaslian, kesejukan, gejala alam, budaya dan sejarah merupakan potensi luar biasa yang dapat dikembangkan menjadi salah satu tujuan wisata. Beberapa kawasan wisata alam yang ada di Sulawesi Utara menggambarkan keanekaragaman sumberdaya alam yaitu berupadanau, pegunungan, pantai, laut, dan air terjun. Salah satunya ialah Air Terjun Kali Tahapan Telu. Objek wisata Air terjun yang berada di Desa Kali ini memiliki ketinggian air terjun 20-60 meter. Objek wisata ini memiliki keadaan alam yang sangat sejuk dan pemandangan yang indah. Pada bagian tertentu kawasan, dapat dilihat hamparan bukit dan laut Sulawesi. Kawasan iniberdekatan dengan daerah Kota Manado dengan jarak tempuh hanya sekitar 30- 40 menit sampai ke pintu masuk kawasan wisata Air Terjun Kali Tahapan Telu. Air Terjunnyasangat unik karena merupakan air terjun bertingkat yang memiliki tiga tingkatan sehingga masyarakat sekitar sering menyebutnya "Tahapan Telu" yang berarti Tiga tingkatan air terjun. Namun pada saat survey awal, terlihat kondisi fasilitas dan sarana prasarana lainnya dalam kondisi tidak terawat, seperti terlihat dari depan tempat papan nama gerbang pintu masuk objek wisata Air Terjun Tahapan Telu dalam keadaan yang berdebu serta cat dan tulisan yang ada di papan nama yang sudah mulai luntur, kemudian terlihat pula keadaan jalan setapak dan anakanak tangga yang licin dan berlumut, pos-pos peristirahatan yang penuh dengan coretan, toilet umum yang kotor dan penuh coretan, tidak tersedianya tempat sampah. Kondisi biofisik yang buruk tentunya menurunkan kepuasan pengunjung dan selanjutnya akan menurunkan minat kunjungan wisata, bahkan dapat berdampak buruk bagi lingkungan. Hal ini melatar belakangi peneliti untuk menginventarisasi kondisi biofisik Air Terjun Tahapan Telu terkait potensinya sebagai kawasan wisata alam.

\section{Rumusan Masalah}

Adapun rumusan masalah dari penelitian ini adalah apa saja potensi wisata dari aspek biofisik kawasan Wisata Alam Air Terjun Kali Tahapan Telu yang dapat dikembangkan?

\section{Tujuan Penelitian}

Penelitian ini bertujuan untuk menganalisis potensi biofisik kawasan Wisata Alam Air Terjun Kali Tahapan Telu.

\section{Manfaat Penelitian}

Penelitian ini diharapkan dapat memberikan informasi mengenai potensi biofisik kawasan Wisata alam air terjun Kali Tahapan Telu, bagi pihak pemerintah daerah dan masyarakat secara umum serta sebagai dasar pertimbangan pengembangan produk obyek dan daya tarik wisata.

\section{METODE PENELITIAN}

\section{Waktu dan Tempat Penelitian}

Penelitian ini dilaksanakan di Air Terjun Kali Tahapan Telu Desa Kali Selatan. Penelitian ini berlangsung pada bulan Agustus 2020.

\section{Metode Pengumpulan Data}

Penelitian ini menggunakan metode survei yang dilakukan dengan observasi langsung ke kawasan Wisata Air Terjun Kali Tahapan Telu dan pengumpulan data berupa data primer dan sekunder. Data primer yang dikumpulkan merupakan seluruh data hasil pengamatan di lapangan (Observasi) serta wawancara dengan pihak pemerintah setempat dan masyarakat 
dengan menggunakan daftar pertayaan mengenai kondisi biofsik, sedangkan data sekunder yang dikumpulkan meliputi seluruh informasi pendukung yang berhubungan dengan penelitian diperoleh dari hasil penelitian sebelumnya, laporan dan diperoleh dari instansi terkait lainnya. Data sekunder yang diambil dalam penelitian ini berupa data keadaan penduduk, kondisi fisik wilaya banyaknya SDA yang menonjol, aksesibilitas, Dokumentasi berbentuk pengambilan gambar juga akan dilakukan guna mendukung data primer.

\section{Metode Analisis Data}

Analisis data yang digunakan dalam penelitian ini adalah dengan teknik skoring. Data yang dikumpulkan mengacu pada pedoman Penilaian Obyek dan Daya Tarik Wisata Alam (ODTWA) PHKA 2003. Pemberian skoring dilakukan dengan kriteria penilaian daya tarik wisata alam, kriteria penilaian aksesibilitas, kriteria penilaian akomodasi, dan kriteria penilaian sarana prasarana penunjang. Jumlah skor/ nilai untuk satu kriteria dihitung dengan persamaan (Aryanto, 2015) :

Keterangan:

$$
\mathrm{S}=\mathrm{N} \times \mathrm{B}
$$

$\mathrm{S}=$ Skor/ Nilai suatu kriteria

$\mathrm{N}=$ Jumlah Nilai unsur-unsur pada kriteria

$\mathrm{B}=$ Bobot Nilai

Kriteria Penilaian di kawasan wisata Air Terjun Kali Tahapan telu sebagai berikut:

1). Daya tarik wisata

$$
\begin{aligned}
& >840-1080 \text { (Tinggi) } \\
& \geq 600-840 \text { (Sedang) } \\
& <600 \text { (Rendah) }
\end{aligned}
$$

2). Aksesibilitas

$>350-450$ (Tinggi)

$\geq 250-350$ (Sedang)

$<250$ (Rendah)

3). Akomodasi

$>70-90$ (Tinggi)

$\geq 50-70$ (Sedang)

$<50$ (Rendah)

4). Sarana dan Prasarana Penunjang

$>140-180$ (Tinggi)

$\geq 100-140$ (Sedang)

$<100$ (Rendah)

\section{HASIL DAN PEMBAHASAN}

\section{Gambaran Umum Lokasi Penelitian}

\section{Letak geografis dan luas wilayah}

Desa Kali Selatan berada pada ketinggian 200-250 meter di atas permukaan laut. Luas wilayah desa Kali Selatan adalah $7.31 \mathrm{~km} 2$ atau $14,82 \%$ dari total luas wilayah Kecamatan Pineleng. Adapun batas wilayah desa Kali Selatan adalah

- Sebelah Utara berbatasan dengan Desa Kali Induk.

- Sebelah Timur berbatasan dengan Desa Koka/Kembes.

- Sebelah Selatan berbatasan dengan Kelurahan Kinilow Kota Tomohon.

- Sebelah Barat berbatasan dengan Kelurahan Tinoor Kota Tomohon.

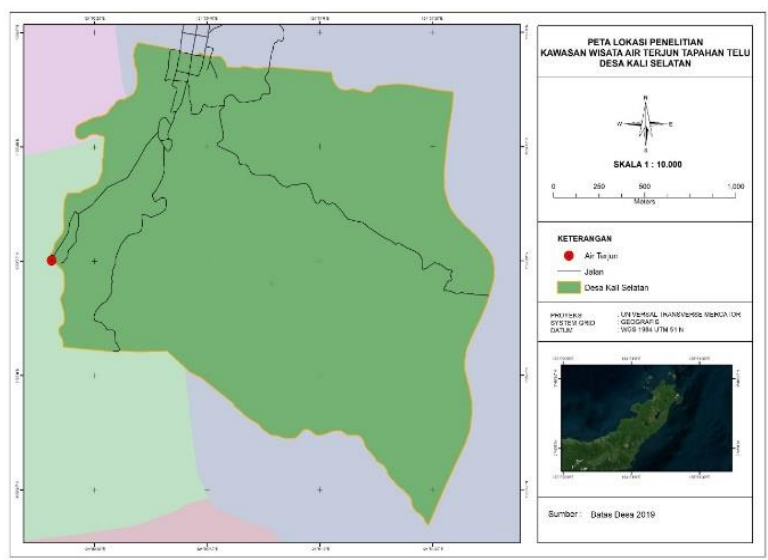

Gambar 1. Peta Desa Kali Selatan

\section{Sejarah}

Air Terjun Kali Tahapan Telu atau Air Terjun Ratahan Telu terletak pada Desa Kali, Kecamatan Pineleng, Kabupaten Minahasa, Provinsi Sulawesi Utara. Air Terjun ini dinamakan Air Terjun Tahapan Telu karena memiliki 3 tahapan air terjun, namun di lokasi hanya dapat melihat tahapan yang terakhir atau yang ketiga. Air terjun tahapan yang ketiga memiliki ketinggian sekitar 60 meter. Tahapan yang terakhir ini airnya mengucur membentuk dua terjunan air yang bersebelahan dan menjadi pemandangan yang indah. 


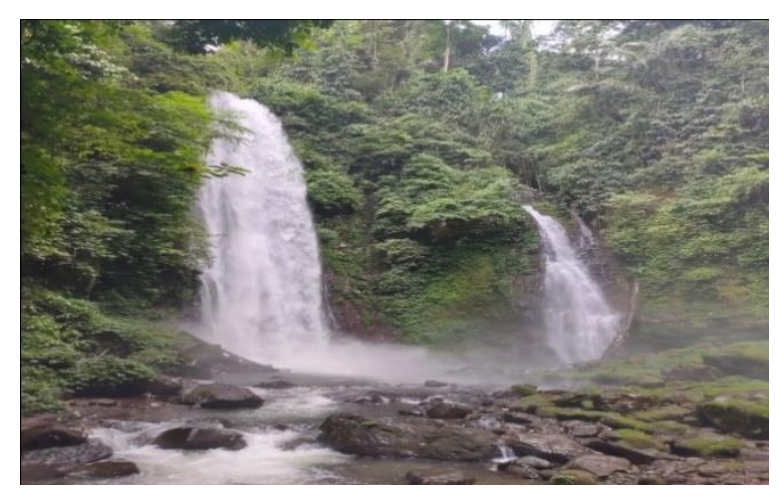

Gambar 2. Tahapan Air terjun Kali yang terakhir

\section{Identitas Responden}

Berikut ini adalah data identitas responden yang diwawancari dalam penelitian ini.

\begin{tabular}{|c|c|c|c|}
\hline No & Nama Responden & Pekerjaan & $\begin{array}{c}\text { Umur } \\
\text { (Tahun) }\end{array}$ \\
\hline 1 & $\begin{array}{l}\text { Drs. Yunus } \\
\text { Tangkuman }\end{array}$ & Hukum tua & 63 \\
\hline 2 & Stenly & $\begin{array}{c}\text { Meweteng (Wakil } \\
\text { Kepala Lingkungan) }\end{array}$ & 35 \\
\hline 3 & Ardy Tilaar & Kepala jaga 4 & 45 \\
\hline 4 & Reni Hawas & Ibu rumah tangga & 42 \\
\hline 5 & Riana Ratu & Ibu rumah tangga & 28 \\
\hline
\end{tabular}

Tabel 1 menunjukkan data responden yang diwawancarai. Adapun dasar pertimbangan pemilihan responden adalah pihak pemerintah setempat (responden 1-3 dan masyarakat yang tempat tinggalnya paling dekat dengan lokasi wisata Air Terjun Tahapan Telu (Responden 4 dan 5). Halaman rumah responden 4 dan 5 sering dijadikan sebagai tempat parkir para pengunjung. Selain itu responden 5 merupakan pemilik warung terdekat dengan objek penelitian.

\section{Potensi Biofisik}

Potensi biofisik wisata alam yang dimaksud dalam penelitian ini adalah seluruh kemampuan, kekuatan lingkungan biotik dan fisik yang dimiliki kawasan wisata dan menjadi daya tarik wisata. Berikut ini adalah hasil observasi terkait potensi biotik dan fisik kawasan wisata yang menjadi kekuatan daya tarik wisata Air Terjun Kali Tahapan Telu.

\section{Aspek Daya Tarik}

Dari hasil observasi di lapangan dan informasi dari masyarakat di sekitar,kawasan wisata Air Terjun Kali Tahapan Telu memiliki daya tarik seperti keindahan alam, sumber daya alam yang menonjol, dan memiliki pilihan berbagai jenis kegiatan, sehingga menarik minat wisatawan atau pengunjung untuk datang ke tempat ini.Untuk mendeskripsikan keindahan alam di lokasi wisata dilakukan dengan melihat potensi view ke arah ke luar lokasi wisata dan potensi view antar bagian air terjun dan arah ke luar air terjun. Titik pandangan ini dilakukan secara terukur dengan pengamatan GPS (Global Positioning System) disertai dokumentasi view.

Di sekitar objek wisata ini terdapat berbagai sumber daya alam menonjol seperti adanya beberapa jenis vegetasi yang dapat dimanfaatkan sebagai pilihan good view kearah luar, dan produksinya diolah masyarakat menjadi produk yang bisa dikonsumsi dan dijual seperti pohon aren, pohon kelapa, pohon pala dan pohon cengkeh. Selain flora, sumber daya alam yang menonjol di lokasi wisata ini yaitu beberapa jenis fauna endemik di lokasi wisata Air Terjun Tahapan Telu. Berikut ini adalah beberapa jenis fauna endemik yang teramati dan atau terdokumentasi masyarakat sekitar kawasan wisata yaitu burung kadalan Sulawesi (Phaenicophaeus calyorhynchus), Ular Viper Hijau Broad Banded Temple Pit Viper (Tropidolaemus laticinctus), Yaki (Macaca Nigra), dan Tarsius (Tarsius spectrum).

Terdapat 5 (lima) pilihan aktivitas wisata di obyek wisata Air Terjun Kali Tahapan Telu yaitu berenang, fotografi, hiking, camping dan kegiatan pendidikan. Saat ini pengunjung paling banyak melakukan kegiatan berenang, dan fotografi. Sedangkan kegiatan hiking dan kegiatan pendidikan (field trip) masih jarang atau sedikit dilakukan di objek wisata, dari hasil observasi di lapangan dan informasi langsung dari masyarakat sekitar obyek wisata.

Terdapat banyak coretan di dindingdinding fasilitas dan juga tidak adanya tempat sampah yang membuat lokasi wisata terlihat semakin tidak terawat.Padahal kebersihan wisata merupakan aspek penting bagi kenyamanan pengunjung.Oleh sebab itu pihak-pihak yang memiliki kepentingan di objek wisata di Air Terjun Kali Tahapan Telu seharusnya memperhatikan kebersihan kawasan wisata Air Terjun Tahapan Telu, seperti yang tertera pada Undang-Undang Kepariwisataan Nomor 10 Tahun 2009 Pasal 5 bahwa memelihara kelestarian alam dan lingkungan hidup merupakan prinsip kepariwisataan. 
Keselamatan /keamanan kawasan wisata ini berkaitan dengan karakteristik topografinya. Menurut Subekti, 2012 daerah yang rawan terhadap tanah longsor dilihat dari topografinya adalah pegunungan dan perbukitan dengan lereng sedang hingga terjal. Ada area dalam kawasan wisata yang terjal dan cukup curam berpotensi menyebabkan tanah longsor sehingga nilai unsur keselamatan/keamanan kawasan tidak maksimal.

\section{Aspek Aksesibilitas}

Berdasarkan data BPS tahun 2019, objek wisata Air Terjun Kali Tahapan Telu yang berada di Desa Kali Selatan berjarak 4 km ke ibukota kecamatan, $27 \mathrm{~km}$ ke ibu kota kabupaten. Berikut adalah gambaran aksesibilitas menuju ke lokasi objek wisata. Akses jalan masuk ke Desa Kali Selatan Kecamatan Pineleng sendiri memiliki lokasi yang berdekatan dengan daerah Kota Manado dan Terminal Karombasan dengan jarak 8-9 $\mathrm{km}$ dengan jarak tempuh hanya sekitar 30 menit sampai ke pintu masuk Air Terjun. Kondisi ini menjadi salah satu faktor penunjang terkait aksesibilitas menuju lokasi objek wisata.

Dari arah Kota Manado pengunjung dapat melalui Jalan Gerbang masuk Tugu Makam Pahlawan Tuanku Imam Bonjol Akses menuju Desa Kali selatan, melalui pusat kota Manado dapat ditempuh dengan kendaraan umum (angkot) di Terminal Karombasan. Angkutan umum akan berhenti di gerbang masuk yang terletak di Kelurahan Lotta, dan pengunjung dapat menggunakan jasa ojek untuk sampai di lokasi Air Terjun Tahapan Telu. Selain itu, akses ke lokasi wisata dapat juga melalui Kota Tomohon.

Pengunjung dapat menggunakan kendaraan umum maupun pribadi untuk ke kawasan wisata ini. Pengunjung wisata dapat memilih jalan dari STFS (Sekolah Tinggi Filsafat Seminari) Pineleng ataupun dari arah Tomohon. Sedangkan Kendaraan umum yang bisa digunakan dari arah Pineleng/Manado adalah mikrolet.
Akses jalan masuk ke lokasi wisata dari pintu masuk yaitu jalan setapak. Untuk menuju ke lokasi air terjun, ditempuh dengan berjalan kaki sekitar 20 menit. Jalan setapak di sekitar pintu masuk berupa perkerasan dalam bentuk paving stone yang memudahkan perjalanan. Selanjutnya ada bagian jalan setapak yang berupa tangga terbuat dari beton. Karena sebagian anak tangga betonitu ditumbuhi lumut, maka kondisinya licin terutama saat atau setelah hujan. Sebagian jalan setapak rusak sehingga membutuhkan perbaikan.

\section{Aspek Akomodasi}

Akomodasi yang ada di objek wisata Air Terjun Kali Tahapan Telu adalah penginap anmilik perorangan. Namun penginapan ini belum dibuka karena masih dalam tahap persiapan untuk dibuka secara umum.

\section{Aspek Sarana Dan Prasarana penunjang}

Sarana penunjang adalah segala sesuatu yang melengkapi dan bertujuan untuk memudahkan proses kegiatan pariwisata dapat berjalan lancar (Ghani, 2015).

Berikut ini adalah sarana yang ada di kawasan wisata Air Terjun Kali Tahapan Telu, parkiran yang ada di lokasi objek wisata adalah pekarangan rumah warga yang dijadikan tempat parkir bagi wisatawan yang mengunjungi tempat wisata. Ukuran lahan parkir adalah panjang $8 \mathrm{~m}$ dan lebar $6 \mathrm{~m}$ dengan daya tampung sekitar 10 kendaraan. Untuk tarif parkiran tidak dipungut biaya dari pihak pengelola wisata, namun warga di sekitar kawasan wisata biasanya memungut tarif parkiran bila diparkir di lahan mereka. Terdapat beberapa warung kecil/kios yang berada di dekat lokasi wisata yang dimiliki warga setempat. Papan informasi penunjuk jalan sangat penting keberadaannya untuk memberikan informasi kepada wisatawan agar tidak salah arah dalam menuju ke suatu objek wisata. Pemasangan papan penanda ini akan mempermudah dan mempercepat wisatawan mencari lokasi ataupun objek wisata. Papan informasi penunjuk jalan menuju objek wisata Air Terjun Tahapan Telu berada di gerbang dan jalan menuju Desa Kali. 
Prasarana adalah sumber daya alam dan sumber daya manusia yang mutlak dibutuhkan oleh wisatawan dalam perjalanannya di daerah tujuan wisata, seperti jalan, listrik, air, telekomunikasi, terminal, jembatan, dan lain sebagainya (Suwantoro dalam Ghani, 2017). Berikut ini adalah prasarana yang terdapat padakawasan wisata Air Terjun Kali Tahapan Telu.Berdasarkan observasi di lapangan, tidak terdapat jalur listrik sebagai prasarana penerangan yang ada di obyek wisata. Terdapat juga aliran air sungai di lokasi wisata yang bisa dijadikan sumber air, namun sayangnya tidak dialirkan ke toilet, sehingga menyebabkan sulitnya pengunjung mendapatkan air bersih untuk kebutuhan MCK. Ada 2 (dua) toilet yang berada di lokasi objek wisata. Kedua toilet tersebut berada dalam kondisi yang tidak terawat. Tidak ada petugas kebersihan atau pengelola yang secara khusus bertanggung jawab memelihara kebersihan toilet.

Terdapat jaringan seluler di obyek wisata namun kadang-kadang jaringan seluler tidak baik jika kondisi hujan. Saat melakukan observasi di objek wisata, semakin ke arah objek wisata, jaringan seluler semakin melemah. Tempat istirahat yang ada di lokasi objek wisata terdapat di beberapa tempat menuju jalur lokasi objek wisata namun dalam kondisi tidak terawatsama seperti toilet yang dindingnya penuh tulisan. Tidak adanya petugas atau pengelola menyebabkan fasilitas di objek wisata kurang terawat.

\section{Analisis Potensi Biofisik Objek Wisata Air Terjun Kali Tahapan Telu}

Penilaian pada kawasan Obyek wisata Air Terjun Kali Tahapan Telu menggunakan pedoman Analisis Daerah Operasi Objek dan Daya Tarik Wisata Alam (ADO-ODTWA) Direktorat Jenderal Perlindungan Hutan dan Konservasi Alam tahun 2003. Hasil penilaian yang didapatkan kemudian dianalisis untuk penilaian potensi yang dimiliki Wisata Alam Air Terjun Tahapan Telu, berpotensi atau tidaknya dalam suatu kawasan.

Berikut ini adalah hasil penilaian setiap komponen potensi objek wisata meliputi daya tarik wisata, aksesibilitas, akomodasi, serta sarana dan prasarana penunjang. Skor total yang diperoleh setiap komponen kemudian dianalisis untuk mengetahui tingkat potensi komponen tersebut.

Tabel 2. Hasil Penilaian Terhadap Komponen Daya Tarik Di Kawasan Obyek Wisata Air Terjun Kali Tahapan Telu

\begin{tabular}{ccccc}
\hline No & $\begin{array}{c}\text { Unsur/Sub } \\
\text { Unsur }\end{array}$ & Bobot & Nilai & $\begin{array}{c}\text { Skor } \\
\text { Total* }\end{array}$ \\
\hline 1 & $\begin{array}{c}\text { Keindahan } \\
\text { Alam } \\
\text { Banyaknya } \\
\text { SDA yang } \\
\text { Menonjol } \\
\text { Kegiatan } \\
\text { wisata alam } \\
\text { yang dapat } \\
\text { dilakukan }\end{array}$ & 6 & 50 & 300 \\
3 & 6 & 20 & 120 \\
4 & $\begin{array}{c}\text { Kebersihan } \\
\text { lokasi objek } \\
\text { wisata } \\
\text { Keselamatan/ } \\
\text { Keamanan } \\
\text { kawasan }\end{array}$ & 6 & 25 & 120 \\
\hline 5 & Skor total \\
& $\mathbf{1 3 0}$ & & 150 \\
\hline
\end{tabular}

Keterangan: Hasil kali antara bobot dengan nilai

Tabel 3. Hasil penilaian terhadap aksesibilitas menuju Kawasan obyek wisata Air Terjun Kali Tahapan Telu.

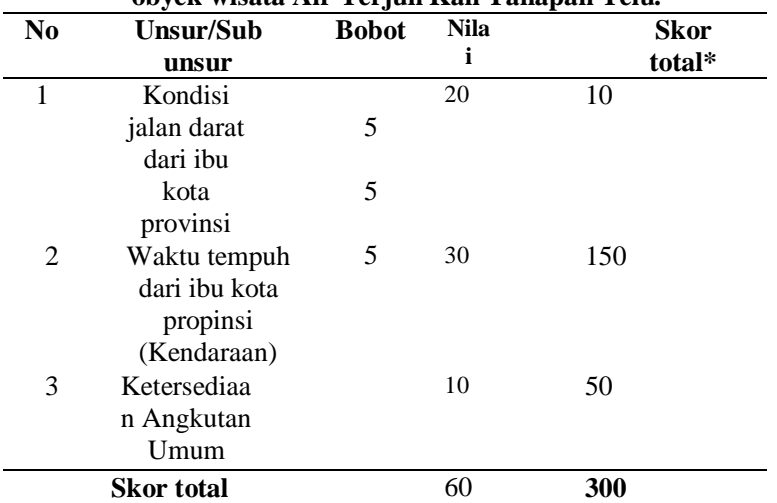

Keterangan: Hasil kali antara bobot dengan nilai Sumber: Data Primer/sekunder 2020

Tabel 4. Hasil penilaian akomodasi sekitar obyek wisata Air Terjun Kali Tahapan Telu (Radius 3 km dari objek).

\begin{tabular}{ccccc}
\hline No. & $\begin{array}{c}\text { Unsur/Sub } \\
\text { unsur }\end{array}$ & Bobot & Nilai & $\begin{array}{c}\text { Skor } \\
\text { Total }\end{array}$ \\
\hline 1 & $\begin{array}{c}\text { Jumlah } \\
\text { penginapan }\end{array}$ & 3 & 15 & 45 \\
\hline & Skor total & & 15 & $\mathbf{4 5}$
\end{tabular}

Keterangan : Hasil kali antara bobot dengan nilai Sumber : Data Primer 2020

Tabel 5. Hasil Penilaian Komponen Sarana Dan Prasarana Di Sekitar Kawasan Obyek Wisata Air Terjun Kali Tahapan Telu.

\begin{tabular}{llccc}
\hline No & $\begin{array}{l}\text { Unsur/Sub } \\
\text { unsur }\end{array}$ & Bobot & Nilai & $\begin{array}{l}\text { Skor } \\
\text { total* }\end{array}$ \\
\hline 1 & Sarana & 3 & 20 & 60 \\
2 & Prasarana & 3 & 20 & 60 \\
\hline & Skor total & & $\mathbf{4 0}$ & $\mathbf{1 2 0}$ \\
\hline
\end{tabular}

Keterangan: Hasil kali antara bobot dengan nilai Sumber: Data Primer 2020 
Dari keempat tabel diatas, dapat diketahui penilaian terhadap unsur dan sub unsur yang berada di obyek wisata Air Terjun Kali Tahapan Telu, yang kemudian dari skorskor di atas akan diolah untuk mengetahui apakah aspek-aspek di obyek wisata Air Terjun Kali Tahapan Telu untuk mengetahui potensi biofisik Untuk hasil penilaiannya dapat dilihat pada tabel di bawah ini:

\begin{tabular}{|c|c|c|c|c|c|c|}
\hline Komponen & $\begin{array}{l}\text { Skor } \\
\text { Maks }\end{array}$ & $\begin{array}{l}\text { Skor } \\
\text { Min }\end{array}$ & Interval* & $\begin{array}{c}\text { Kriteria } \\
\text { Potensi }^{\star *}\end{array}$ & $\begin{array}{c}\text { Skor } \\
\text { Total**} \\
\star \\
\end{array}$ & Ket. \\
\hline $\begin{array}{l}\text { Penilaian } \\
\text { Daya Tarik } \\
\text { Wisata }\end{array}$ & 1080 & 360 & 240 & $\begin{array}{c}>840-1080 \\
\text { (Tinggi) } \\
\geq 600-840 \\
\text { (Sedang) } \\
<600 \\
\text { (Rendah) }\end{array}$ & 780 & Sedang \\
\hline $\begin{array}{l}\text { Penilaian } \\
\text { Aksesibilitas }\end{array}$ & 450 & 150 & 100 & $\begin{array}{c}>350-450 \\
\text { (Tinggi) } \\
250-350 \\
\text { (Sedang) } \\
<250 \\
\text { (Rendah) }\end{array}$ & 300 & Sedang \\
\hline $\begin{array}{l}\text { Penilaian } \\
\text { Akomodasi }\end{array}$ & 90 & 30 & 20 & $\begin{array}{c}>70-90 \\
(\text { Tinggi) } \\
50-70 \\
\text { (Sedang) } \\
<50 \text { (Rendah) }\end{array}$ & 45 & Rendah \\
\hline $\begin{array}{l}\text { Penilaian } \\
\text { Sarana dan } \\
\text { Prasarana } \\
\text { Penunjang }\end{array}$ & 180 & 60 & 40 & $\begin{array}{c}>140-180 \\
\text { (Tinggi) } \\
100-140 \\
\text { (Sedang) } \\
<100 \\
\text { (Rendah) }\end{array}$ & 120 & Sedang \\
\hline
\end{tabular}

Keterangan: *Skor maksimum dikurangi skor minimum bagi tiga

**Kriteria kelas kelayakan berdasarkan interval

***Skor tertinggi untuk setiap kriteria

Sumber: Data Primer 2020

Berdasarkan hasil perhitungan pada (tabel 5) menunjukkan bahwa kawasan obyek wisata Air Terjun Kali Tahapan Telu berpotensi. Disimpulkan demikian karena dari 4 (empat) kriteria potensi komponen, ada 3 (tiga) kriteria dengan potensi sedang (potensi daya tarik, aksesibilitas dan sarana dan prasarana penunjang) dan 1 (satu) kriteria dengan potensi rendah yaitu akomodasi.

Terkait potensi daya tarik wisata dengan skor total 780, sekalipun tergolong kategori sedang, adanya potensi view di dalam objek wisata serta adanya beberapa sumber daya yang menonjol seperti keindahan flora dan kelangkaan fauna, serta pesona air terjun menjadi sub unsur yang memegang peranan penting dalam kualitas daya tarik objek wisata.

Aspek daya tarik wisata menjadi aspek yang sangat penting dan memegang peranan dalam kelayakan sebuah objek wisata. Hal ini sesuai dengan apa yang disampaikan oleh Arafah dan Alamsyah (2012) bawa daya tarik objek wisata merupakan suatu faktor yang membuat orang berkeinginan untuk mengunjungi dan melihat secara langsung ke suatu tempat yang menarik.

Terkait aspek aksesibilitas, berdasarkan hasil survey objek wisata memiliki lokasi yang berdekatan dengan daerah Kota Manado dan Terminal Karombasan dengan jarak 8-9 km dengan jarak tempuh hanya sekitar 30 menit sampai ke pintu masuk Air Terjun. Kondisi ini menjadi salah satu faktor penunjang terkait aksesibilitas menuju lokasi objek wisata. Selain itu tersedianya berbagai fasilitas angkutan umum menjadi salah satu faktor yang mendukung terhadap kemudahan aksesibilitas menuju lokasi objek wisata. Meskipun angkutan umum hanya sampai di Desa Lotta dan harus lanjut menggunakan angkutan umum lainnya seperti ojek menuju objek wisata, score total potensi aksesibilitas 300 tergolong kategori sedang. Hal ini sejalan dengan apa yang dikatakan Arafah dan Alamsyah (2012) bahwa kemudahan aksesibilitas sebuah objek wisata merupakan suatu indikasi objek tersebut cukup mudah dijangkau.

Untuk aspek sarana dan prasarana penunjang, juga berada pada kategori sedang dengan skor total 120. Sarana dan prasarana penunjang juga sangat penting dalam kehadiran sebuah objek wisata. Peranan dari sarana dan prasarana berguna untuk menunjang kemudahan dan kepuasan pengunjung (Arafah dan Alamsyah, 2012). Namun ketersediaan sarana dan prasarana penunjang perlu didukung dengan upaya pengelolaan dan pemeliharaan dari pihak pengelola atau stakeholder yang berkepentingan dengan objek wisata.

Selain 3 (tiga) aspek di atas dengan kategori sedang, ada 1 (satu) aspek yang memiliki skor total kategori rendah. Dari 4 (empat) potensi yang dianalisis, terdapat 1 (satu) aspek yang termasuk kategori rendah dengan skor total 45 yaitu aspek akomodasi.

Hal ini sesuai dengan kondisi yang ada di lapangan yaitu belum tersedianya akomodasi penginapan yang bisa digunakan pengunjung atau wisatawan karena belum dibuka.Selama ini 
pengunjung biasanya menginap di kamar yang disewakan oleh warga setempat dan fasilitas yang diberikan pun masih dapat dibilang minim.Padahal kegiatan wisata memerlukan fasilitas akomodasi, dalam hal ini adalah adanya sarana yang cukup untuk penginapan khususnya bagi pengunjung yang berasal dari tempat yang jauh (Arafah dan Alamsyah, 2012).

Berdasarkan hasil analisis potensi biofisik kawasan Wisata Air Terjun Kali Tahapan Telu (Tabel 5) menunjukan beberapa potensi biofisik yang dapat dikembangkan. Potensi yang dapat dikembangkan seperti Potensi biofisik bernilai sedang. Penilaian aspek daya tarik, aspek aksesibilitas, dan aspek sarana dan prasarana penunjang menghasilkan nilai sedang. Sedangkan aspek akomodasi mendapatkan nilai rendah. Berikut ini adalah rekomendasi pengembangan kawasan wisata berdasarkan potensi aspek biofisik.

\section{Aspek Daya Tarik}

Potensi biofisik yang dimiliki kawasan objek wisata Air Terjun Kali Tahapan Telu memiliki daya tarik yang bisa dinikmati oleh wisatawan. Untuk memanfaatkan potensi biofisik objek wisata Air Terjun Kali perlu dilakukan penambahan pilihan kegiatan wisata misalnya outbound, arung jeram, dan panjat tebing, serta pengembangan aktivitas wisata edukasi yang belum dikelola dengan baik. Pengembangan ini juga berfungsi untuk mengurangi beban yang ada pada obyek wisata air terjun. Kawasan wisata alam ini termasuk tipe titikkonsentrasi (node) yang memiliki karakteristik berupa objek khusus yang cenderung memusatkan pengunjung pada suatu titik atau area yang kecil serta memberikan kemudahan pengelolaan komersial tetapi dapat mengakibatkan kerusakan objek wisata dan mengurangi kualitas pengunjung. Oleh karena itu dibutuhkan pengelolaan berdasarkan prinsip-prinsip berwawasan lingkungan dan berkelanjutan. Berwawasan lingkungan artinya mempertimbangkan kelestarian dan jangan sampai menimbulkan dampak negatif bagi lingkungan hidup. Kegiatan edukasi (khususnya pendidikan lingkungan) juga dapat dikembangkan dengan koordinasi bersama Instansi Pemerintah terkaitmencakup pengenalan jenis-jenis flora maupun fauna khas daerah dan endemik, arsitektur dan seni budaya daerah, dan life skill in nature.

Pengembangan potensi biofisik dapat dilakukan dengan melalui desain lanskap yangm mendukung pengelolaan keanekaragaman hayati termasuk tanaman endemic, terutama di dalam kawasan dan juga sekitarnya (Saroinsong, 2020). Dengan demikian dapat meningkatkan daya tarik dengan menambah keanekaragaman kekayaan alam yang bisa dinikmati sekaligus, menunjang konservasi, serta menjadi wahana edukasi mengenai sumber daya lokal. Khususnya untuk pengelolaan lanskap sekitar kawasan wisata, pelibatan masyarakat dapat digalang melalui diseminasi tentang pengelolaan ruang terbuka hijau pemukiman yang meningkatkan biodiversitas flora (Saroinsong dan Kalangi, 2018).

Terkait peningkatan nilai guna lahan pertanian secara tidak langsung, keberadaan lahan pertanian masyarakat di sekitar kawasan yang ditanami tanaman-tanaman yang memiliki ciri khas daerah Sulawesi Utara yaitu cengkeh, kelapa, aren dan pala dimanfaatkan dan ditunjang dengan desain lanskap dalam kawasan wisata alam yang berfungsi sebagai bingkai atau latar depan pemandangan tersebut sehingga menambah daya tarik wisata (Saroinsong, 2020). Selain itu, peningkatan nilai guna lahan pertanian secara langsung sekaligus sejalan dengan pemberdayaan masyarakat yaitu pengolahan bagian hasil lahan pertanian masyarakat yang tidak diperdagangkan dikembangkan untuk menjadi cenderamata yang sampai saat ini belum disediakan. Pemberdayaan masyarakat juga dilakukan dengan melibatkan masyarakat sekitar dalam menambah daya tarik wisata yaitu dengan atraksi wisata khususnya atraksi budaya daerah.

Penyambutan wisatawan di pintu masuk objek wisata atau penyelenggaraan atraksi kesenian khas daerah di waktu-waktu tertentu akan menarik minat pengunjung. Hal lain yang bisa dikembangkan yaitu penyewaan baju tradisional, serta penyediaanphotobooth yang didesain untuk menampilkan arsitektur khas secara khusus dan atau budaya Sulawesi Utara secara umum. 


\section{Aspek aksesibilitas}

Untuk kriteria aksesibilitas mendapatkan kriteria potensi sedang, hal ini dapat dilihat akses jalan dari pusat kota Provinsi, lebar jalan, dan tipe jalan yang digunakan menuju ke objek wisata Air Terjun Kali mempermudah akses bagi pengunjung hal ini perlu kerjasama dengan travel agency maupun pihak penginapan ataupun masyarakat sekitar objek wisata alam Air Terjun Kali, mempromosikan wisata melalui internet. Selain itu, kerjasama dengan pihak travel juga merupakan salah satu cara yang dapat dilakukan dalam pemasaran suatu objek wisata. Melalui kerjasama yang saling menguntungkan antara objek wisata dengan pihak travel, maka diharapkan Kawasan wisata Air Terjun Kali Tahapan Telu dapat dikenal masyarakat luas.

\section{Aspek Akomodasi}

Akomodasi merupakan salah satu faktor penting bagi pengunjung objek wisata. Akomodasi merupakan salah satu faktor yang membuat pengunjung tertarik untuk melakukan suatu kunjungan wisata. Pengembangan akomodasi yang dilakukan antara lain menyediakan homestay bagi pengunjung, memberikan penyuluhan dan pembinaan kepada masyarakat mengenai pelayanan prima, dan memaksimalkan ketersediaan fasilitas yang lengkap.

\section{Sarana dan prasarana penunjang}

Dalam promosi dan inovasi pariwisata harus didukung dengan ketersediaan sarana dan prasarana yang menarik dalam obyek wisata, sehingga mampu mempengaruhi pengunjung untuk datang. Dalam mengembangkan fasilitas umum di lokasi objek wisata adalah sarana dan prasarana serta infrastruktur yang menunjang seperti gardu pandang, membuat atraksi atau event pada waktu-waktu tertentu dan memaksimalkan perbaikan fasilitas umum yang telah ada, sehingga menarik dan memberi kenyamanan bagi pengunjung.

Salah satu potensi alam yang dimiliki objek wisata ini adalah pemandangan air terjun yang sangat indah. Kualitas view panorama air terjun menjadi daya tarik yang bisa dinikmati oleh wisatawan. Namun layanan informasi pada kawasan wisata alam Air Terjun Kali Tahapan Telu masih sangat kurang. Diperlukan tambahan papan informasi sebagai sumber informasi yang dapat mengarahkan para wisatawan ke titik-titik dengan view yang menarik, penambahan papan informasi bertujuan memberikan layanan informasi atau untuk menggambarkan suatu area kepada para wisatawan.

\section{KESIMPULAN DAN SARAN}

\section{Kesimpulan}

Berdasarkan hasil analisis potensi biofisik dengan menggunakan teknik skoring, maka diperoleh bahwa hasil potensi biofisik Air Terjun Kali Tahapan Telu termasuk kategori sedang. Pengembangan kawasan wisata dapat dilakukan dengan memanfaatkan berbagai potensi biofisik sekaligus mengatasi kendala yang ditemui. Penambahan dan pengembangan pilihan aktivitas wisata, penambahan dan pengkayaan good view melalui desain lanskap yang menarik, pengelolaan keanekaragaman hayati termasuk jenis endemik, pemanfaatan arsitektur khas dalam bangunan penunjang, pemanfaatan seni dan budaya daerah dalam meningkatkan daya tarik wisata, penambah infrastruktur berupa gardu pandang atau gazebo, serta penyediaan cenderamata berbasis sumber daya lokal.

\section{Dalam upaya mengoptimalkan} pengembangan kawasan Air Terjun Kali Tahapan Telu, diharapkan kerja sama yang baik antara Pemerintah daerah dan pemerintah setempat bersama masyarakat. Bentuk kegiatan dimulai dari upaya perencanaan pengembangan yang matang dan sistem manajemen pengelolaan yang terorganisir sehingga selain meningkatkan ekonomi kepariwisataan, juga dapat meningkatkan ekonomi pertanian setempat, sambil memperkuat pemberdayaan masyarakat. Diperlukan juga pelatihan kepada masyarakat lokal mengenai kepariwisataan agar masyarakat sadar akan pentingnya potensi wisata di daerahnya yang harus dilestarikan, sehingga mereka dapat berpartisipasi baik dalam menjaga 
kebersihan maupun mengamankan kawasan lokasi wisata.

$\begin{array}{cl}\text { Diharapkan } & \text { dengan adanya } \\ \text { peningkatan sistem pemeliharaan dan }\end{array}$
pengembangan objek wisata, maka para wisatawan dapat menikmati objek wisata dengan rasa aman dan nyaman. Jika daya tarik wisata Air Terjun Kali Tahapan Telu semakin diminati banyak orang maka pasti memberikan keuntungan baik kepada masyarakat setempat maupun pemerintah. Serta perlu dilakukan penelitian lebih lanjut tentang penyusunan strategi pengembangan potensi biofisik ada di Air Terjun Kali Tahapan Telu.

\section{DAFTAR PUSTAKA}

Arafah, N., dan Flamin, A., 2012.Analisis Kelayakan Pengembangan Ekowisata Di kawasan Hutan Lindung Kecamatan Anggaberi Kabupaten Konawe Provinsi Sulawesi Tenggara. Fakultas Kehutanan Universitas HaluoleoKendari. Kendari.Jurnal Layanan Kehutanan Masyarakat, Vol 1 No 1.

Aryanto, T. 2015. Potensi Ekowisata Jalur Pendakian Bukit Raya di Taman Nasional Bukit Baka Bukit Raya Kalimantan Barat. Prosiding. Seminar Nasional Pengelolaan Sumber Daya Alam dan Lingkungan. Semarang: Kampus Pascasarjana Universitas Diponegoro.

Badan Pusat Statistik Kabupaten Minahasa, 2019. Kecamatan Pineleng Dalam Angka 2019. Kabupaten Minahasa: Badan Pusat Statistik.

Ghani, Y. A. 2015. Pengaruh Inovasi Sarana Prasarana Terhadap Kepuasan Pengunjung Di Objek Wisata Karangsetra Waterland. Jurnal Pariwisata.
Ghani, Y. A. 2017. Pengembangan Sarana Prasarana Destinasi Pariwisata Berbasis Budaya di Jawa Barat.Jurnal Pariwisata.

Jibran, M. 2016. Potensi pengembangan daya tarik wisata di kecamatan Marawola Barat kabupaten Sigi. Jurnal Pendidikan Geografi.

[PHKA] Perlindungan Hutan dan Konservasi Alam.2003 (a). Pedoman Analisis Daerah Operasi Objek dan Daya Tarik Wisata Alam (ADO-ODTWA). Direktorat Jenderal Perlindungan Hutan dan Konservasi Alam. Bogor.

Ridwan, M. 2012. Perencanaan Pariwisata dan Pengembangan Pariwisata, Medan Polonia: PT. Sofmedia.

Saroinsong, F. B. dan Kalangi, J. I. 2018.Diseminasi Pengelolaan RTH Pemukiman untuk Meningkatkan Biodiversitas Flora. Edupreneur Vol 1(3):54-61.

Saroinsong, F. B. 2020. Supporting plant diversity and conservation through landscape planning: A case study in an agro-tourism landscape in Tampusu, North Sulawesi, Indonesia.Biodiversitas Journal of Biological Diversity 21(4):1518-1526. DOI: 10.13057/biodiv/d210432

Subekti, Aji B. 2012. Tingkat Kerawanan Longsor lahan dengan Metode Weight of Evidence di Sub-DAS Secang Kabupaten Kulonprogo.Skripsi. Fakultas Geografi, Universitas Gadjah Mada. 